
cycle of an extinct Cretaceous oyster

Niels J. de Winter et al.

Correspondence to: Niels J. de Winter (niels.de.winter@vub.be)

The copyright of individual parts of the supplement might differ from the CC BY 4.0 License. 


\section{Supplement files}

All supplementary files are stored in the open access online database Zenodo and can be accessed using the following link: https://doi.org/10.5281/zenodo.3699542

S1: High resolution (6400 dpi) scans of cross sections through the 12 shells of Rastellum diluvianum used in this study.

S2: Compilation of $\mu \mathrm{XRF}$ maps of cross sections through the 12 shells of Rastellum diluvianum used in this study.

S3: Compilation of XRF line scans measured through the foliated calcite of Rastellum diluvianum shells.

S4: Compilation of LA-ICP-MS data collected within the context of this study.

S5: Compilation of IRMS data used in this study.

S6: Composite figures of XRF linescan data through the shells of Rastellum diluvianum.

S7: Source code of the bivalve growth model adapted from Judd et al. (2018) including temperature equations for calcite.

S8: Compilation of strontium isotope data and ages used in this study.

S9: Compilation of the results from growth modelling on 5 Rastellum diluvianum shells.

S10: Compilation figures of proxy record data plotted on time axis for all 5 shells for which modelling was carried out.

S11: Plot of ontogenetic trends in $\delta^{13} \mathrm{C}$ and $\mathrm{Li} / \mathrm{Ca}$ proxies including statistics on the spread of the slopes of these trends.

S12: Data on trends in $\delta^{13} \mathrm{C}$ and $\mathrm{Li} / \mathrm{Ca}$.

S13: Data used to create seasonality crossplots shown in Fig. 7.

S14: Data on statistics of the growth rates, seasonality and spawning season of all 5 bivalves for which modelling was done. 